\begin{tabular}{|l|l|l||}
\hline \multicolumn{2}{|c|}{ PublisherInfo } \\
\hline \hline PublisherName & $:$ & Palgrave Macmillan UK \\
\hline \hline PublisherLocation & $:$ & London \\
\hline \hline PublisherImprintName & $:$ & Palgrave Macmillan \\
\hline
\end{tabular}

\title{
Economic Review, May 2007
}

\begin{tabular}{|c|c|}
\hline \multicolumn{2}{|c|}{ ArticleInfo } \\
\hline ArticleDOI & 10.1057/palgrave.elmr.1410069 \\
\hline ArticleCategory & Economic Review \\
\hline ArticleFirstPage & 6 \\
\hline ArticleLastPage & 13 \\
\hline \multirow{2}{*}{ ArticleHistory } & RegistrationDate : 2007-5-18 \\
\hline & : 2007-5-18 \\
\hline ArticleCopyright & Crown copyright 2007 \\
\hline
\end{tabular}


Anis Chowdhury, ${ }^{\text {Aff1 }}$

\section{Monthly review of economic and labour market trends in the UK.}

GDP continued to grow robustly in 2007 quarter one, driven mainly by the services sector, with little contribution from manufacturing output. On the expenditure side in 2006 quarter four, robust business investment continued to drive growth, supported by a pick up in household spending. As a reflection of the UK's dynamic domestic demand profile and unfavourable exchange rate position, the trade deficit widened in 2006 quarter four. The current account deficit also widened. The Labour market shows tentative signs of weakening and average earnings remain subdued. The public sector finances improved in March 2007. Consumer and producer output price inflation rose in March 2007.

Misc

The Full Text of this article can be found on the National Statistics website (http://www.statistics.gov.uk/downloads/theme_economy/EconReview_0507.pdf). 